\title{
Pollen Load and Flower Constancy of Stingless Bees Tetragonula laeviceps (Smith) and Heterotrigona itama (Cockerell) (Apidae: Meliponinae)
}

\author{
Muchamad Nur Cholis ${ }^{1}$, Resi Alpionita ${ }^{1}$, Taruni Sri Prawasti ${ }^{1}$, Tri Atmowidi ${ }^{1 *}$ \\ ${ }^{I}$ Department of Biology, Faculty of Mathematics and Natural Science, IPB University, Bogor 16680, Indonesia \\ *Corresponding author.Email: atmowidi@apps.ipb.ac.id
}

\begin{abstract}
Stingless bees are pollinating insects that are important for plants and useful for producing honey. The role of stingless bees as pollinators related to the activity of foraging on flowers. The aim of this study was to measure pollen load and flower constancy of two species stingless bees, Tetragonula laeviceps and Heterotrigona itama in the campus area of IPB University, Bogor. As many as 30 individuals of T. laeviceps and H. itama from different nest colonies were used. Each individual of bee was collected in a $1.5 \mathrm{~mL}$ microtube containing $0.5 \mathrm{~mL} \mathrm{70 \%} \mathrm{ethanol:} \mathrm{glycerol} \mathrm{(4:} \mathrm{1).} \mathrm{The} \mathrm{results} \mathrm{showed} \mathrm{that} \mathrm{the} \mathrm{highest} \mathrm{pollen} \mathrm{load}$ occurred in $T$. laeviceps (122,594 pollen grains) followed by $H$. itama (56,575 pollen grains). Tetragonula laeviceps showed $78.32 \%$ flower constancy in Polygonaceae, $74.05 \%$ in Amaranthaceae, and $70.76 \%$ in Solanaceae plants. Meanwhile, Heterotrigona itama showed $73.16 \%$ flower constancy in Polygonaceae. The pollen load and flower constancy of $T$. laeviceps and H. itama varied according to the location of the nest.
\end{abstract}

Keywords: flower, nest, stingless bee

\section{INTRODUCTION}

Stingless bees (Apidae: Meliponinae) are eusocial and generalist insects [1]. The nectar and pollen are used as main sources of nutrition, while resin and latex are used to build and protect their nests [2]. Their foraging activities in flowers help pollination of plants [3]. Stingless bee is an effective pollinator, they have a special structure of pollen collectors (corbicula) to help pollen transfer to other flowers $[4,5]$.

Pollen has two layers consisting of exine (outer) and intine (inner) [6]. Size is one of the character that can be used for pollen identification. Based on the size, pollen can be grouped into a very small pollen $(<10 \mu \mathrm{m})$, small $(10-25 \mu \mathrm{m})$, medium $(25-50 \mu \mathrm{m})$, large $(50-100 \mu \mathrm{m})$, very large $(100-200 \mu \mathrm{m})$, and giant $(>200 \mu \mathrm{m})$ [4]. Identification of pollens also based on the observation of polarity, symmetry, aperture, shapes and sizes [4]. Various families of plants are visited by stingless bees, such as Acanthaceae, Begoniaceae, Cucurbitaceae, Ciperaceae, Poaceae, Malvaceae, Myrtaceae, Rutaceae, Euphorbiaceae, and Leguminosae [7-10]

The foraging activity of $T$. laeviceps can be shown by the value of flower constancy. Flower constancy is the interest of the forager to visit one species of flower in one flight trip [11]. The aim of this study was to calculate flower constancy during foraging activities of $T$. laeviceps and H. itama and the ability to carry pollen (pollen load) in different nest locations.

\subsection{Materials and Methods}

\subsubsection{Sample collection and morphological observation of Tetragonula laeviceps and Heterotrigona itama}

Sample collection was conducted on March-April 2019 of T. laeviceps and H. itama nests in three different locations in IPB University campus Dramaga: Department of Biology area (location 1), Faculty of Fisheries and Marine Sciences area (location 2), and guess house area (location 3). Stingless bees carried the pollens were collected individually during the return to the nest. Morphological and body size observations of stingless bees were carried out on 10 individuals of $T$. laeviceps and $H$. itama, respectively.

\subsubsection{Pollen extraction from Tetragonula} laeviceps and Heterotrigona itama

Each individual of $T$. laeviceps and $H$. itama were collected then put into a $1.5 \mathrm{~mL}$ microtube containing a solution of $0.5 \mathrm{~mL}$ of $70 \%$ ethanol: glycerol (4: 1). Each tube was filled by one individual of stingless bee. The pollen separation used acetolysis method with modification. Sample was centrifuged in $3500 \mathrm{rpm}$ for $5 \mathrm{~min}$ then stingless bee was removed. Solution was centrifuged in $2000 \mathrm{rpm}$ for 3 minutes, then supernatant was removed, leaving pollen deposits [12]. Pollen deposits were then added by $1 \mathrm{~mL}$ acetolysis solution 
(9 acetic anhydrides: 1 acetic acid). The tube was heated in 80 ${ }^{\circ} \mathrm{C}$ in the water bath for 5 minutes then supernatant was removed. The remaining deposits were rinsed with distilled water and then was centrifuged in 2000 rpm for 3 minutes, then supernatant was removed by leaving $0.1 \mathrm{~mL}$ of pollen deposit.

\subsubsection{Pollen identification}

Identification of pollen was carried out based on Pollen Flora of Taiwan [13], Atlas of the Tropical West African Pollen Flora 14] and The Australasian Pollen and Spore Atlas (website: https//apsa.anu.edu.au) [19].

\subsubsection{Measurement of pollen load and flower constancy}

As much as $0.1 \mathrm{~mL}$ of pollen deposits were calculated to determine pollen load and flower constancy of stingless bees. Pollen was counted by using haemocytometer for four replications. Flower constancy was calculated based on the percentage of dominant pollen type during a single trip of stingless bee [11].

\subsubsection{Data analysis}

Flower constancy and pollen load of T. laeviceps and $H$. itama were shown in scatter plots. The relationship of body size and pollen load were analysed by General Linear Model (GLM) analysis using the PAST Statistic 3.20 program.

\subsection{Our Contribution}

This paper presents several additions based on research conducted by Pengestika et al. [10]. First, the additional bee sampling from different colony locations. Second, the analysis of relationship between pollen load and stingless bee body size. Pollen load and flower constancy of stingless bee varied based on locations. Stingless bees body size affected the total pollen loads. The larger body size does not always carry more pollens because it depends on the pollen size. The smaller pollen size, more pollens can be carried by stingless bee.

\subsection{Paper Structure}

This paper was organized as follows. Section 1 introduces the biology of stingless bees, pollen morphology, pollen identification, and measurement of pollen load and flower constancy. Section 2 presents the results and discussion of pollen size, pollen load, and flower constancy. Section 3 is the conclusion of the research that has been done.

\section{RESULTS AND DISCUSSION}

\subsection{Identification of Pollen Plants}

Based on the observations, several types of pollen attached to $T$. laeviceps and H. itama. The pollen types were poliplicate pollen types (Figure 1B), pantoporate types (Figure 1C), monocolpate (Figure 1E;G), inaperturate (Figure 1D), tricolporate (Figure 1A), pantocolporate (Figure 1I), tetrad (Figure 1F), tricolporate (Figure 1J), dicolporate (Figure 1K) and labeled (Figure 1L).

Pollens have various types such as monoporate, monocolpate, diporate, dicolporate, triporate, tricolpate, tricolporate, inaperturate, syncolpate, tetrad, and polyads [14]. The diversity of pollen types that were found showed that $T$. laeviceps and $H$. itama were generalist insects that visit various kinds of plants for food sources [1]. These characteristics make foraging activities are greatly influenced by the types of plants around the nest.

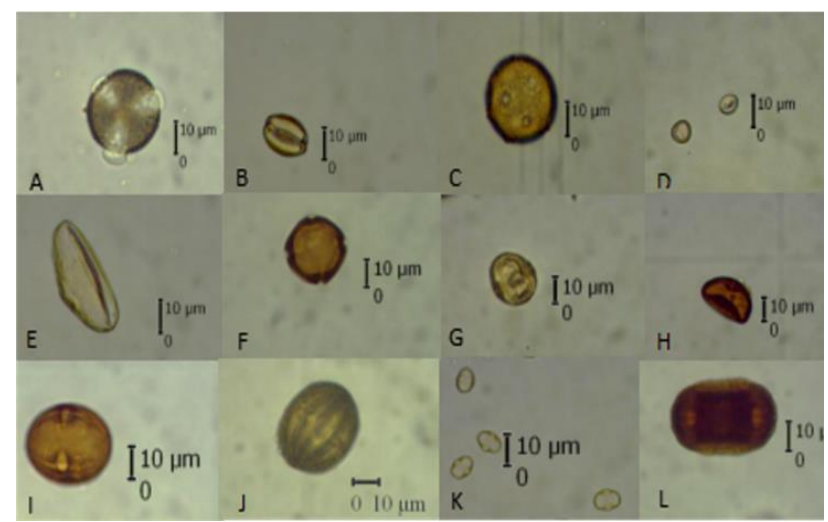

Figure 1 Type of pollen plant: (A) Polygonaceae, (B) Rutaceae, (C) Amaranthaceae, (D) Unidentified (sp. 1), (E) Arecaceae 1, (F) Rubiaceae, (G) Leguminoceae, (H) sp. 2, (I) Verbenaceae, (J) Vitaceae, (K) Solanaceae, (L) Acanthaceae

\subsection{Pollen Load and Body Size of Tetragonula laeviceps and Heterotrigona itama}

The average body size of $T$. laeviceps was $3.85 \pm 0.17 \mathrm{~mm}$ and H. itama was $5.78 \pm 0.09 \mathrm{~mm}$ (Figure 2). The average of pollen load on stingless bees collected in three locations varied. The highest pollen load occurred on $T$. laeviceps (in guest house) (122,594 pollen grains) followed by H. itama (56,575 pollen grains), T. laeviceps (in location of Faculty of Fisheries) (34,369 pollen grains) and T. laeviceps (in area Dept. of Biology) (18,275 pollen grains) (Figure 3). 


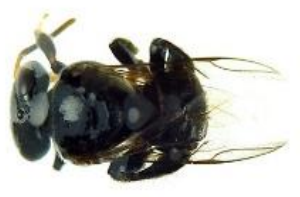

a

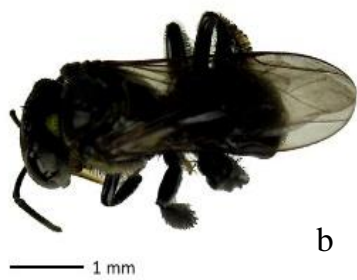

Figure 2 Morphological characteristics of: (a) Tetragonula laeviceps, (b) Heterotrigona itama

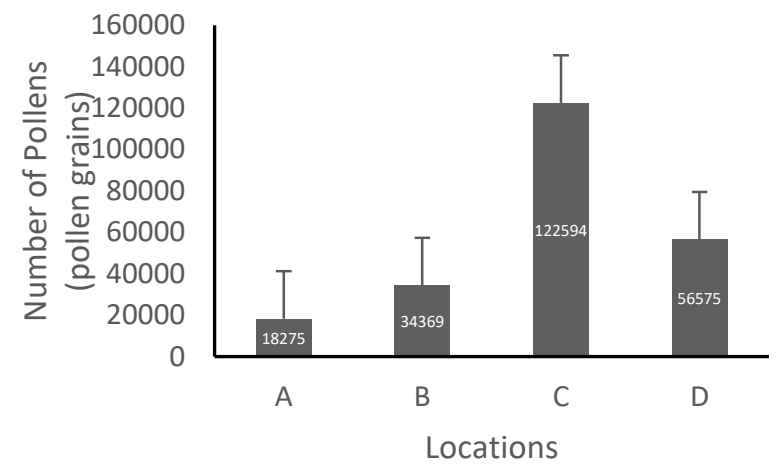

Figure 3 Pollen load of Tetragonula laeviceps in location 1, location 2, location 3 (A-C), and Heterotrigona itama in location 1(D). Standard errors are shown in the graphic

Relationship between pollen load and body size showed that there was no positive effect on the number of pollen carried $\left(y=-30983 x+240415 R^{2}=0.0215\right)$ (Figure 4). The size of T. laeviceps was smaller than H. itama, but has a higher number of pollen loads (in location 3). Pollen attached on $T$. laeviceps and $H$. itama varied in size. At location 1, pollen found was categoryzed as medium-size (Polygonaceae, Amaranthaceae, Arecaceae), small-size (Rutaceae), and verysmall size (unidentified sp1). In the location 2, pollen found was categoryzed in medium (Amaranthaceae), small (Rubiaceae, Leguminoceae, unidentified sp 2), and very small (Solanaceae). In the location 3, pollen found was in the medium category (Arecaceae, Acanthaceae).

Pollens were deposited on corbicula structure located in the hind-legs tibia of worker bees. Pollen load is used to determine the ability of bees to carry pollen which plays in pollinating flowers [12]. On stingless bees, pollens were commonly found on the thorax, tarsus, and curbicula [15]. Pollen load of $T$. laeviceps that has a smaller body size, was higher than H. itama. The number of pollen load is associated with the size of carried pollen which mostly has a very small size than the pollen category $(<10 \mu \mathrm{m})[4]$.

The results of this study showed that the body size did not affect the amount of pollen carried. These results were different compared to other research conducted by Pangestika et al. 2017 [10] and Veiga et al. 2013 [16] that showed the larger body size, the more pollen can be carried. The results of General Linear Model analysis showed that the larger body size did not always carry more pollens because it depend on the size of the pollen. The smaller pollen size, more pollen could be carried.

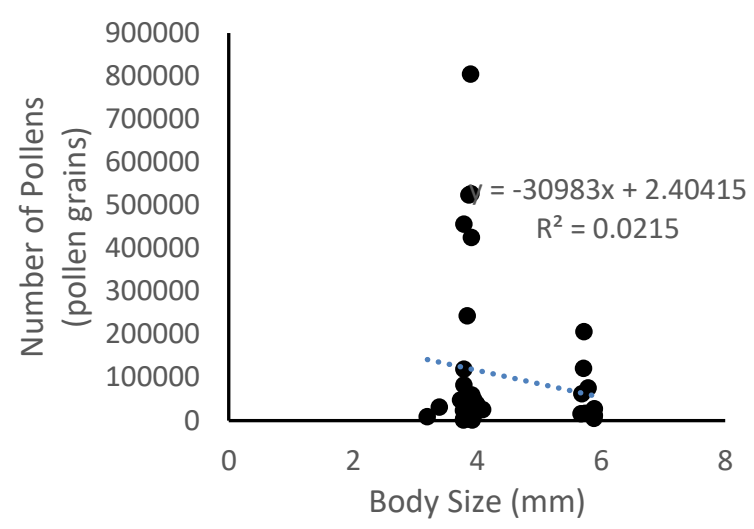

Figure 4 Relationship between pollen load and body size of stingless bees

\subsection{Flower Constancy in $\mathrm{T}$. laeviceps and $\mathrm{H}$. itama}

Pollen attached to $T$. laeviceps varied in three nestslocations. It showed differences in the dominance of plants visited. The dominant type of pollen attached on the body of $T$. laeviceps in location 1,2 , and 3 were pollens of Polygonaceae (78.32\%), Amaranthaceae (74.05\%), and Solanaceae $(70.76 \%)$, respectively. The pollens load on the $H$. itama was dominated by Polygonaceae (73.16\%) (Figure 5).

The percentage of flowers visited depend on the plants in around the nest and the availability of foods. Pollinator prefers to choose flowers that are easily accessible with simple morphological feature [18]. Location 2 had diverse species of plants. Six plants families were identified based on pollens attached on stingless bees. Location 2 was an open area and surrounded by many flowering plants as a source of food. Stingless bee feed the pollens as a source of protein and nectar as a source of carbohydrate.

\section{CONCLUSION}

The pollen load and flower constancy of T. laeviceps and $H$. itama varied based on location of the nest. The highest pollen load was found on T. laeviceps (122,594 pollen grains) followed by $H$. itama (56,575 pollen grains). The dominant type of pollens attached on the body of T. laeviceps in location 1, 2, and 3 were pollens of Polygonaceae (78.32\%), Amaranthaceae $(74.05 \%)$, and Solanaceae $(70.76 \%)$, respectively. The pollen load on $H$. itama was dominated by Polygonaceae $(73.16 \%)$. 

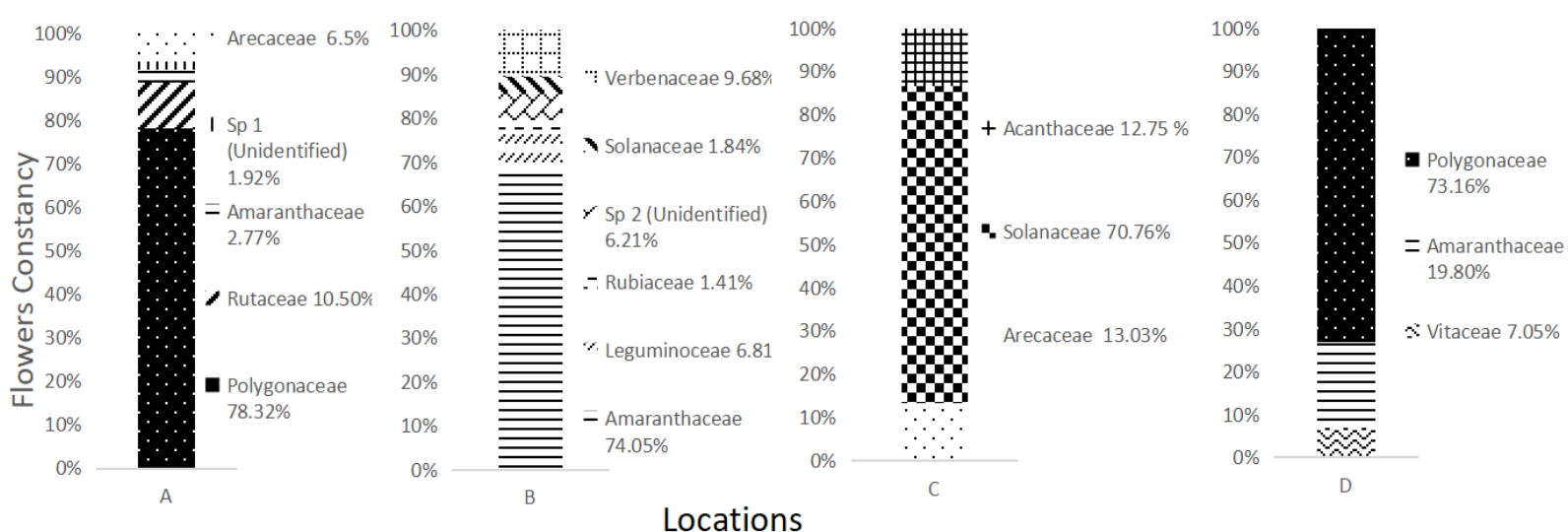

Figure 5 Flower constancy of T. laeviceps in location 1-3 (A-C) and H. itama in location 1 (D)

\section{ACKNOWLEDGMENT}

This research was funded by Penelitian Dasar Unggulan Perguruan Tinggi (PDUPT), Ministry of Research, Technology, and Higher Education, Republic of Indonesia: Tri Atmowidi (3/E1/KP.PTNBH/2019).

\section{REFERENCES}

[1] Y. Boontop, S. Malaipan, K. Chareansom, D. Wiwatwittaya, Diversity of stingless bees (Apidae: Meliponini) in Thong Pha Phum District, Kanchanaburi Province, Thailand, Kasetsart J. Nat. Sci. 42 (2008) 444-456

[2] S.F. Sakagami, Stingless bees Hermann H.R, editor Social Insects Vol. 3. New York: Academia Pr, 1982, pp. 361-423

[3] T.A. Heard, The Role of Stingless Bees in Crop Pollination. Annu. Rev. Entomol. 44 (1999) 183-206. DOI: https://doi.org/10.1146/annurev.ento.44.1.183

[4] G. Erdtman, Handbook of palynology an introduction to the study of pollen grains and spore. New York: Hafner Publishing Company, 1969, pp 1486

[5] M. Gastauer, L.A.O. Campos, D. Wittmann, Handling sticky resin by stingless bees (Hymenoptera, Apidae). Rev. Bras. Entomol. 55 (2) (2011) 234-240. DOI: https://doi.org/10.1590/S0085-56262011005000018

[6] N.R. Lersten, Flowering Plant Embryology: With Emphasis on Economic Species. Iowa:WileyBlackwell, 2004, 23p

[7] M.S. Engel, F.D. Bakels, Nectar and Pollen Resources for Stingless Bees (Meliponinae,
Hymenoptera) in Suriname (South America). Apidologie. 11 (4) (1980) 341-350

[8] M. Ramalho, T.C. Giannini, K.S. Malagodi-Braga, V.L. Imperatriz-Fonseca, Pollen Harvest by Stingless Bee Foragers (Hymenoptera, Apidae, Meliponinae). Grana 33 (4-5) (1994) 239-244. DOI: https://doi.org/10.1080/00173139409429005

[9] E.J. Slaa, L.A. Sanchez, M.B. Sampaio, F.E. Hofstede, Stingless Bees in Applied Pollination: Practice and Perspectives. Apidologie. 37 (2) (2006) 293-315.

DOI: http://dx.doi.org/10.1051/apido:2006022

[10] N.W. Pengestika, T. Atmowidi, S. Kahono, Pollen Load and Flower Constancy of Three Species of Stingless Bees (Hymenoptera, Apidae, Meliponinae). TLSR. 28 (2) (2017) 179-187. DOI: https://doi.org/10.21315/tlsr2017 .28.2.13

[11] N.M. Waser, Flower Constancy: Definition, Cause, and Measurement. Am. Nat. 127 (5) (1986) 593-603

[12] A. Dafni, Pollination ecology a practical approach. New York: Oxford University Press, 1992, pp. $217-$ 219

[13] T.C. Huang, Pollen flora of Taiwan (Taiwan: National Taiwan University, 1972, pp. 1-297

[14] W.D. Gosling, C.S. Miller, D.A. Livingstone, Atlas of the tropical West African pollen flora, Rev. Palaeobot. Palyno. 199 (2013) 1-135. DOI: https://doi:10.1016/ j.revpalbo.2013.01.003

[15] Y.M. Chan, L.G. Saw, Notes on the pollination ecology of the palm genus Johannesteijsmannia (Arecaceae). J. Pollinat. Ecol. 6 (15) (2011) 108-117

[16] J.C. Veiga, C. Menezes, G.C. Venturieri, F.A.L. Contrera, The bigger, the smaller: relationship 
between body size and food stores in the stingless bee Melipona flavolineata, Apidologie. 44 (3) (2013) 324-333. DOI: https://doi:10.1007/s13592-0120183-4

[17] R.W. Shuel, The Production of Nectar and Pollen (Illinois: Dadant and Sons Hamilton, 1992, pp. 401436

[18] C. Gruter, F.L.W. Ratnieks, Flower Constancy in Insect Pollinators, Comm. Integr. Bio. 4 (6) (2011) 633-636. DOI: https://doi: 10.4161/cib.4.6.16972

[19] C. Weng, P. Shimeld, D. Bowman, S. Van Der Kaars, K. Sniderman, The Australasian Pollen and Spore Atlas V1.0. Australian National University, Canberra. http://apsa.anu.edu.au 